\title{
Analgesic and Anti-inflammatory Properties of Essential Oil from Ageratum fastigiatum
}

\author{
Glauciemar Del-Vechio-Vieira ${ }^{1}$, Orlando Vieira de Sousa ${ }^{3 *}$, Mariza Abreu Miranda ${ }^{3}$, Luci \\ Senna-Valle ${ }^{1}$ and Maria Auxiliadora Coelho Kaplan ${ }^{1,2}$ \\ ${ }^{I}$ Departamento de Botânica; Museu Nacional; ${ }^{2}$ Núcleo de Pesquisa de Produtos Naturais; Universidade Federal do \\ Rio de Janeiro; Ilha do Fundão; 21941-590; Rio de Janeiro - RJ - Brasil. ${ }^{3}$ Departamento Farmacêutico; Faculdade \\ de Farmácia e Bioquímica; Universidade Federa de Juiz de Fora; 36036-330; Juiz de Fora - MG - Brasil
}

\begin{abstract}
The chemical composition, analgesic and anti-inflammatory properties of essential oil from Ageratum fastigiatum were investigated. The main compounds found in the essential oil were germacrene $D, \alpha$-humulene and $\beta$-cedrene. The oil, with $L D_{50}$ of $2.50 \mathrm{~g} / \mathrm{kg}$, inhibited the acetic acid-induced writhing at the dose of $200 \mathrm{mg} / \mathrm{kg}$. In the formalin test, the oil inhibited the first phase $(200 \mathrm{mg} / \mathrm{kg})$ and the second phase (100 mg/kg and $200 \mathrm{mg} / \mathrm{kg})$. In the hot plate test, after 30 and $60 \mathrm{~min}$ of treatment the doses of 100 and $200 \mathrm{mg} / \mathrm{kg}$ increased the reaction time. The antiedematogenic effect, reduction on the exudate volume and leukocyte mobilization were observed at the doses of 100 and $200 \mathrm{mg} / \mathrm{kg}$. The results indicated that A. fastigiatum possessed the analgesic and anti-inflammatory properties that supported the popular medicinal use of the plant.
\end{abstract}

Key words: Ageratum fastigiatum, Essential oil, Nociception, Inflammation

\section{INTRODUCTION}

The family Asteraceae is one of the largest plant family with over 1000 genera and 25000 species and growing at different habitats. In Brazil, this family is represented by about 300 genera and 2000 species (Souza and Lorenzi, 2005). Many plants from this family possess the medicinal properties and most of them have been found to possess analgesic, anti-inflammatory and antimicrobial activities (Lorenzi and Matos, 2002). The genus Ageratum consists of approximately 30 species but only few species have been chemically investigated (Okunade, 2002). A. conyzoides is the most studied species from the chemical and biological point of views (Okunade, 2002; Bouda et al., 2001; Singh et al., 2002; Shirwaikar et al.,
2003; Moody et al., 2004; Nébié et al., 2004; Moura et al., 2005).

Ageratum fastigiatum (Gardn.) R. M. King et $\mathrm{H}$. Rob. is a plant well distributed in Minas Gerais State, Southestern Brazil (Almeida et al., 2004; Guimarães et al., 2002). This plant, popularly called in Brazil as "matapasto", grows commonly in open place, thrives in any garden soil and is often found at dirty and ruined sites (Almeida et al., 2004). Phytochemical studies have identified diterpenes, triterpenes and derivatives from $A$. fastigiatum (Bohlmann et al., 1981; Bohlmann et al., 1983). This plant, as well as A. conyzoides, is indicated in folk medicine as anti-inflammatory, analgesic and antimicrobial (Lorenzi and Matos, 2002; Carvalho, 2004).

\footnotetext{
*Author for correspondence: orlando.sousa@ufjf.edu.br
} 
Despite the popular use of leaf extracts from $A$. fastigiatum for the pain relief and treatment of inflammation, there have been no published reports about this plant, and therefore, the present work studied the dried leaf essential oil analgesic and anti-inflammatory activities in experimental animal models. In addition, the chemical composition and acute toxicity of the essential oil were also studied.

\section{MATERIALS AND METHODS}

\section{Plant Material}

The plant material used in this study was collected in São João Del-Rei, State of Minas Gerais, Brazil in March 2005. The species was identified by Dr. Roberto Lourenço Esteves, and a voucher specimen $\left(n^{\circ}\right.$ 10329) has been deposited in the Herbarium of the State University of Rio de Janeiro (UERJ), Rio de Janeiro, Brazil.

\section{Extraction and Identification of Essential Oil}

Dried leaves $(400 \mathrm{~g})$ of $A$. fastigiatum were hydrodistilled in a Clevenger-type apparatus. After $4 \mathrm{~h}$ of distillation, the essential oil (EO) was removed from the surface of the water and dried over anhydrous sodium sulphate for analysis. In order to evaluate the analgesic and antiinflammatory activities and the acute toxicity, each $500 \mathrm{mg}$ of essential oil was solubilized with $100 \mu \mathrm{l}$ of dimethyl sulphoxide (DMSO) followed by saline.

Analysis of the volatile constituents was performed on a Hewlett Packard series 6890 gas chromatograph coupled to mass spectrometer MS HP5972 under the following analytical conditions: ZB-5MS column $(30 \mathrm{~m} \times 0.25 \mathrm{~mm} \times 0.25 \mu \mathrm{m}$ film thickness); helium (1 $\mathrm{mL} / \mathrm{min})$; programmed temperature $60^{\circ}-240^{\circ} \mathrm{C} \quad\left(3^{\circ} \mathrm{C} / \mathrm{min}\right)$; injector temperature $\left(260^{\circ} \mathrm{C}\right)$ and interface $\left(200^{\circ} \mathrm{C}\right)$; ionization energy, $70 \mathrm{eV}$; scan range, 30-300 amu; scan time, $1 \mathrm{~s}$. Compounds identification was based on a comparison of retention indices (determined relatively to the retention times of a series of n-alkanes), mass spectra and the NIST spectrometer data bank besides comparison with literature data (Adams, 1995).

\section{Animals}

Male Wistar rats weighing 180-240 $\mathrm{g}$ and male Swiss mice weighing 25-30 $\mathrm{g}$ were used in the experiments in accordance with previous estimate. The animals were divided into groups of 4 mice or 3 rats and kept in plastic cages $(47 \times 34 \times 18 \mathrm{~cm})$ at room temperature $\left(25 \pm 4^{\circ} \mathrm{C}\right)$, with free access to Purina rations and water. Animal care and the experimental protocol followed the principles and guidelines suggested by the Brazilian College of Animal Experimentation (COBEA) and were approved by the Ethical Committee of the Federal University of Juiz de Fora (protocol number 001/2006 - CEEA). All the experiments were performed between 08:00-12:00 $\mathrm{h}$ to avoid circadian influences.

\section{Chemicals}

Drugs and reagents employed in this study (and their sources) were as follows: acetic acid (Vetec Química Farm. Ltda, Rio de Janeiro, Brazil), formaldehyde (Reagen Quimibrás Ind. Química S. A., Rio de Janeiro, Brazil), morphine hydrochloride (Merck Inc., USA), naloxone, indomethacin and carrageenan (Sigma Chemical Co, USA).

\section{Acute Toxicity}

Group of ten mice received doses of $0.5,1,1.5,2$ and $3 \mathrm{~g} / \mathrm{kg}$ of essential oil from A. fastigiatum, while the control group received the vehicle (saline) by orogastric route. The groups were observed for $48 \mathrm{~h}$ and at end of this period the mortality was recorded for each group (Dietrich, 1983). The $\mathrm{LD}_{50}$ were determined by probit test using a death percent versus doses' log (Litchfield and Wilcoxon, 1949). The determination of $\mathrm{LD}_{50}$ served to define the doses used in the experiments of analgesic and anti-inflammatory activities.

Acetic Acid-Induced Writhing Response in Mice Analgesic activity was evaluated by the test of abdominal writhing induced by acetic acid in mice (Koster et al, 1959). The animals were divided into five groups of eight mice each. Acetic acid 0.6\% $(0.25 \mathrm{ml})$ was injected intraperitoneally to the control mice group and $10 \mathrm{~min}$ later the writhes were counted over a period of $20 \mathrm{~min}$. Among the remaining groups one received orally the reference indomethacin $(10 \mathrm{mg} / \mathrm{kg})$ and the other three groups of eight mice each received orally the $A$. fastigiatum essential oil in the doses 50, 100 and $200 \mathrm{mg} / \mathrm{kg}$ one hour before the acetic acid, as the control group. 


\section{Formalin-Induced Nociception in Mice}

Groups of mice treated as above were injected subplantar with $20 \mu \mathrm{l}$ of $2.5 \%$ formalin (in $0.9 \%$ saline) and the duration of paw licking was determined 0-5 min (first phase) and 15-30 min (second phase) after formalin injection (Hunskaar and Hole, 1987). Animals $(\mathrm{n}=8)$ were pretreated with essential oil $(50,100$ or $200 \mathrm{mg} / \mathrm{kg}$, p.o.; 0.1 $\mathrm{ml} / 10 \mathrm{~g}$ body weight) or morphine $(5 \mathrm{mg} / \mathrm{kg}$, s.c.) 1 hour before formalin administration. Control animals were treated with similar volume of sterile saline $(10 \mathrm{ml} / \mathrm{kg}$ body weight). Morphine (5 $\mathrm{mg} / \mathrm{kg}$, s.c.) was used as reference drug.

\section{Hot plate Latence Assay in Mice}

Tree groups of eight mice each were treated with essential oil (50, 100 or $200 \mathrm{mg} / \mathrm{kg}$, p.o.; $0.1 \mathrm{ml} / 10$ $\mathrm{g}$ body weight) and the control group received sterile saline $(10 \mathrm{ml} / \mathrm{kg})$. The animals were placed on a Hot-Plate (Model LE 7406, Letica Scientific Instruments, Spain) heated at $55 \pm 1^{\circ} \mathrm{C}$ (Franzotti et al, 2000). Measurements were performed at time zero (0 time) and 30, 60 and $90 \mathrm{~min}$ after drug administration, with a cut-off time of $40 \mathrm{~s}$ to avoid animal paw lesion. In a separate group of animals, the effect of pretreatment with naloxone $(1 \mathrm{mg} / \mathrm{kg}$, s.c.) on the analgesia produced by essential oil $(200 \mathrm{mg} / \mathrm{kg}$, p.o.) was determined. Morphine (5 $\mathrm{mg} / \mathrm{kg}$, s.c.) in the absence and presence of naloxone treatment was used as a reference drug in all the experiments.

\section{Edema Induced by Carrageenan in Rats}

Anti-inflammatory activity was assessed on the basis of paw edema inhibition induced by the injection of $0.1 \mathrm{ml} 2 \%$ carrageenan into the subplantar region of the right hind paw of the rat (Winter et al., 1962). Male Wistar rats were divided into three different groups of six animals each that separatedly received the essential oil (50, 100 and $200 \mathrm{mg} / \mathrm{kg}$ p.o; $0.1 \mathrm{ml} / 10 \mathrm{~g}$ body weight), saline and indomethacin $(10 \mathrm{mg} / \mathrm{kg})$ orally $1 \mathrm{~h}$ before the injection of carrageenan. Paw volume was measured after $4 \mathrm{~h}$ intervals of the administration of carrageenan using a plethysmometer (model LE 7500, Letica Scientific Instruments, Spain).

\section{Pleurisy Induced by Carrageenan in Rats}

The pleurisy was induced in male Wistar rats by intrapleural administration of $0.5 \mathrm{ml}$ of $2 \%$ carrageenan suspension in saline solution between the third and fifth ribs on the right side of the mediastinum (Vinegar et al., 1973). Essential oil $(50,100$ and $200 \mathrm{mg} / \mathrm{kg})$ was given per 60 minutes prior to injection of the irritant $(n=6)$. Four hours after carrageenan, the animals were killed and the skin and pectoral muscles retracted. A longitudinal incision was made between the third and fifth ribs on each side of the mediastinum. The exudate was collected and transferred to a $15 \mathrm{ml}$ conical centrifuge tube and the total volume was determined. A $50 \mu \mathrm{l}$ aliquot of exudates was used to determine the total leukocyte count in Neubauer chambers.

\section{Statistical analysis}

The data were expressed as mean \pm S.E.M. Statistical significance was analyzed by the oneway analysis of variance (ANOVA), followed by Student Newman-Keuls test. P-values less than $0.05(\mathrm{p}<0.05)$ were used as the significant level.

\section{RESULTS}

The dried leaves of A. fastigiatum yielded $1.2 \%$ of essential oil. Thirty compounds were identified in this oil, representing $99.99 \%$ of the total oil (Table $1)$. The main compounds were germacrene $\mathrm{D}$ (24.15\%), $\alpha$-humulene $(11.15 \%)$ and $\beta$-cedrene $(10.63 \%)$. Other components occurring in the sample in significant amounts were $\alpha$-pinene, $\delta$ cadinene, $\alpha$-muurolene and $\beta$-gurjunene. The essential oil consisted of monoterpenes $(9.50 \%)$ and sesquiterpenes $(90.49 \%)$.

The essential oil from A. fastigiatum was toxic for mice, with $\mathrm{LD}_{50}$ of $2.50 \mathrm{~g} / \mathrm{kg}$ and confidence interval $95 \%(1.50-4.27)$. This value was important to define the doses for pharmacological activities.

The essential oil from A. fastigiatum leaves at the dose of $200 \mathrm{mg} / \mathrm{kg}$ caused $30.29 \%(42.87 \pm 2.31)$ inhibition $(p<0.001)$ against acetic acid-induced abdominal constrictions on average compared to control (61.50 \pm 2.26$)$ (Table 2). In the formalin test, the analgesic effect was observed after the treatment of animals with essential oil at the dose $200 \mathrm{mg} / \mathrm{kg}$. 
Table 1 - Percentage composition of the essential oil from A. fastigiatum dried leaves.

\begin{tabular}{|c|c|c|}
\hline Compound & Retention Indices & Percentage \\
\hline$\alpha$-pinene & 807 & 9.50 \\
\hline$\delta$-elemene & 1091 & 1.22 \\
\hline$\alpha$-cubebene & 1103 & 0.48 \\
\hline$\alpha$-copaene & 1125 & 1.53 \\
\hline$\beta$-bourbonene & 1131 & 0.63 \\
\hline$\beta$-elemene & 1136 & 1.84 \\
\hline$\beta$-cedrene & 1166 & 10.63 \\
\hline$\beta$-gurjunene & 1168 & 3.77 \\
\hline aromadendrene & 1174 & 0.29 \\
\hline$\alpha$-guaiene & 1178 & 1.26 \\
\hline$\alpha$-humulene & 1186 & 11.15 \\
\hline$\gamma$-muurolene & 1201 & 0.74 \\
\hline germacrene D & 1205 & 24.15 \\
\hline valencene & 1218 & 2.64 \\
\hline$\alpha$-muurolene & 1221 & 5.72 \\
\hline$\gamma$-cadinene & 1228 & 2.78 \\
\hline$\delta$-cadinene & 1234 & 7.03 \\
\hline cadina-1,4-diene & 1245 & 0.45 \\
\hline$\alpha$-cadinene & 1248 & 0.45 \\
\hline elemol & 1261 & 0.43 \\
\hline spathulenol & 1277 & 0.60 \\
\hline caryophyllene oxide & 1280 & 0.87 \\
\hline globulol & 1282 & 0.49 \\
\hline humulene epoxide II & 1300 & 1.08 \\
\hline 1,10-di-epi-cubenol & 1309 & 2.98 \\
\hline 1-epi-cubenol & 1314 & 0.32 \\
\hline epi- $\alpha$-cadinol & 1333 & 1.65 \\
\hline$\alpha$-muurolol & 1356 & 1.60 \\
\hline$\alpha$-bisabolol & 1442 & 1.25 \\
\hline cedryl acetate & 1537 & 2.46 \\
\hline
\end{tabular}

Table 2 - Effects of essential oil from A. fastigiatum dried leaves on acetic acid-induced writhing in mice

\begin{tabular}{lccc}
\hline Group & Doses $(\mathbf{m g} / \mathbf{k g})$ & Number of writhing & Inhibition (\%) \\
\hline Control & Saline & $61.50 \pm 2.26$ & - \\
& 50 & $57.00 \pm 2.13$ & 7.32 \\
Essential oil & 100 & $54.00 \pm 2.68$ & 12.19 \\
& 200 & $42.87 \pm 2.32^{* * *}$ & 30.29 \\
Indomethacin & 10 & $18.00 \pm 1.79^{* * *}$ & 70.73
\end{tabular}

Each value represents the mean \pm S.E.M. of 8 mice. ${ }^{* * *} p<0.001$ significantly different from the control group.

Table 3 - Effects of the essential oil from A. fastigiatum dried leaves on formalin-induced nociception in mice

\begin{tabular}{lccccc}
\hline Group & Doses $(\mathbf{m g} / \mathbf{k g})$ & \multicolumn{4}{c}{ Paw licking (s) } \\
\cline { 2 - 6 } & & First phase & Inhibition (\%) & Second phase & Inhibition (\%) \\
\hline Control & Saline & $89.37 \pm 2.85$ & - & $94.12 \pm 2.15$ & - \\
& 50 & $89.12 \pm 2.97$ & - & $93.37 \pm 2.14$ & - \\
Essential oil & 100 & $86.62 \pm 2.62$ & 3.08 & $79.12 \pm 3.16^{* *}$ & 15.94 \\
& 200 & $63.00 \pm 2.74^{* * *}$ & 29.51 & $53.87 \pm 2.29^{* * *}$ & 42.76 \\
Morphine & 5 & $15.37 \pm 2.15^{* * *}$ & 82.80 & $11.25 \pm 1.81^{* * *}$ & 88.05 \\
\hline
\end{tabular}

Each value represents the mean \pm S.E.M. of 8 mice. ${ }^{* *} p<0.01 ;{ }^{* * *} p<0.001$ significantly different from the control group. 
The effect of the essential oil from A. fastigiatum on animals assayed in the hot plate varied according the doses and observation time used (Table 4). At time zero, no significant antinociceptive effect was observed after the treatment with the essential oil at any doses tested when compared to control. Observing the results obtained after 30 and $60 \mathrm{~min}$ of the treatment, animals that received $100 \mathrm{mg} / \mathrm{kg}(14.37 \pm 0.37)$ or $200 \mathrm{mg} / \mathrm{kg}(18.12 \pm 0.44)$ doses increased the reaction time significantly. At $90 \mathrm{~min}$, only the dose of $200 \mathrm{mg} / \mathrm{kg}$ differed significantly from the control. Morphine showed a potent analgesic response after 30,60 and $90 \mathrm{~min}$ after stimuli, increasing the reaction time by 170,209 and $268 \%$, respectively as compared to control animals.

Hot plate test was further performed in the presence naloxone, an opioid antagonist. Naloxone reduced the morphine-induced antinociceptive effect. However, this antagonist did not alter the essential oil antinociceptive effect (Table 4).

The anti-inflammatory effect of $A$. fastigiatum in rat paw edema induced by carrageenan was tested using essential oil administered orally (Table 5). Inhibition of edema observed at the dose of 100 $\mathrm{mg} / \mathrm{kg}$ showed a $20.00 \%$ reduction in edema $(0.68 \pm 0.09)$ compared to control $(0.85 \pm 0.13)$. The dose of $200 \mathrm{mg} / \mathrm{kg}$ was more active reducing $41.18 \%(0.50 \pm 0.09)$. These results indicated that the essential oil from A. fastigiatum had antiedematogenic properties in the model of carrageenan-induced edema.

The effects of essential oil from A. fastigiatum on carrageenan-induced pleurisy were evaluated comparatively through determination of pleural exudates volume and total leukocyte counts in the exudates. Essential oil administrated 4 hour prior to intrapleural injection of carrageenan, in doses of 100 and $200 \mathrm{mg} / \mathrm{kg}$, significantly reduced exudates volume (Table 6) and leukocyte mobilization (Table 7).

Table 4 - Effects of the essential oil from A. fastigiatum dried leaves on the latency time of mice exposed to the hot plate test

\begin{tabular}{lccccc}
\hline Group & Doses & \multicolumn{4}{c}{ Reaction time (s) } \\
\cline { 2 - 6 } & $(\mathbf{m g} / \mathbf{k g})$ & Time 0' & Time 30' & Time 60' & Time 90' \\
\hline Control & Saline & $6.38 \pm 0.60$ & $6.75 \pm 0.60$ & $6.75 \pm 0.73$ & $6.75 \pm 0.50$ \\
& 50 & $7.00 \pm 0.60$ & $7.38 \pm 0.80$ & $8.38 \pm 0.60$ & $8.75 \pm 0.86$ \\
Essential oil & 100 & $7.12 \pm 0.44$ & $13.62 \pm 0.70^{* * *}$ & $14.38 \pm 0.38^{* * *}$ & $9.12 \pm 0.67^{*}$ \\
& 200 & $7.12 \pm 0.72$ & $15.75 \pm 0.60^{* * *}$ & $18.12 \pm 0.74^{* * *}$ & $15.63 \pm 0.50^{* * *}$ \\
Morphine & 5 & $6.88 \pm 0.44$ & $18.25 \pm 0.60^{* * *}$ & $20.88 \pm 0.72^{* * *}$ & $24.88 \pm 0.74^{* * *}$ \\
Naloxone+Morphine & $1+5$ & $6.63 \pm 0.60$ & $12.75 \pm 0.60^{* *}$ & $11.50 \pm 0.68^{* * *}$ & $10.12 \pm 0.93^{* *}$ \\
Naloxone+Essential oil & $1+200$ & $7.00 \pm 0.46$ & $16.25 \pm 0.60^{* * *}$ & $17.12 \pm 0.50^{* * *}$ & $15.00 \pm 0.71^{* * *}$ \\
\hline
\end{tabular}

Each value represents the mean \pm S.E.M. of 8 mice. ${ }^{*} p<0.05 ;{ }^{* *} p<0.01 ;{ }^{* * *} p<0.001$ significantly different from the control group.

Table 5 - Effects of the essential oil from A. fastigiatum dried leaves on the rat paw edema induced by carrageenan

\begin{tabular}{lccc}
\hline Group & Doses $(\mathbf{m g} / \mathbf{k g})$ & Volume of hind paw $(\mathbf{m l})$ & Inhibition $(\%)$ \\
\hline Control & Saline & $0.85 \pm 0.13$ & - \\
& 50 & $0.82 \pm 0.13$ & 3.53 \\
Essential oil & 100 & $0.68 \pm 0.09$ & 20.00 \\
& 200 & $0.50 \pm 0.09^{* *}$ & 41.18 \\
Indomethacin & 10 & $0.45 \pm 0.10^{* * *}$ & 47.06 \\
\hline
\end{tabular}

Each value represents the mean \pm S.E.M. of 6 rats. ${ }^{* *} p<0.01 ;{ }^{* * *} p<0.001$ significantly different from the control group.

Table 6 - Effects of the essential oil from A. fastigiatum dried leaves on the pleural exudation induced by carrageenan in rats

\begin{tabular}{lccc}
\hline Group & Doses $(\mathbf{m g} / \mathbf{k g})$ & Exudate volume $(\mathbf{m l})$ & Inhibition $(\%)$ \\
\hline Control & Saline & $2.03 \pm 0.10$ & - \\
& 50 & $1.85 \pm 0.08$ & 8.87 \\
Essential oil & 100 & $1.50 \pm 0.11^{* *}$ & 26.11 \\
& 200 & $1.07 \pm 0.09^{* * *}$ & 47.29 \\
Indomethacin & 10 & $1.03 \pm 0.10^{* * *}$ & 49.26 \\
\hline
\end{tabular}

Each value represents the mean \pm S.E.M. of 6 rats. ${ }^{* *} p<0.01 ;{ }^{* * *} p<0.001$ significantly different from the control group. 
Table 7 - Effects of the essential oil from A. fastigiatum dried leaves on number of leukocytes induced by carrageenan in rats

\begin{tabular}{lccc}
\hline Group & Doses $(\mathbf{m g} / \mathbf{k g})$ & $\mathbf{N}^{\mathbf{0}}$ of leukocytes $\left(\mathbf{x ~ 1 0} \mathbf{~ c e l l s}_{\left.\mathbf{~} \mathbf{m m}^{\mathbf{3}}\right)}\right.$ & Inhibition $(\boldsymbol{\%})$ \\
\hline Control & Saline & $22.12 \pm 0.21$ & - \\
& 50 & $21.92 \pm 0.34$ & 12.47 \\
Essential oil & 100 & $19.37 \pm 0.24^{* *}$ & 24.41 \\
& 200 & $16.72 \pm 0.21^{* * *}$ & 35.71 \\
\hline
\end{tabular}

Each value represents the mean \pm S.E.M. of 6 rats. ${ }^{* *} p<0.01 ;{ }^{* * *} p<0.001$ significantly different from the control group.

\section{DISCUSSION}

The A. fastigiatum essential oil showed very few monoterpenes while the sesquiterpenes constituted more than $90.0 \%$ of the identified components, Germacrene D (24.15\%) being the main constituent. Some identified constituents in this species have been also reported in A. conyzoides (Okunade, 2002; Nébié et al. 2004), Chamomilla recutita (Presibella et al., 2006) and Rosmarinus officinalis (Atti-Santos et al., 2005).

Results observed in this study showed this to be the first report describing the antinociceptive and anti-inflammatory activities from A. fastigiatum. The results demonstrated that the essential oil decreased the abdominal constriction, indicating the inhibition of the expression of prostaglandin synthesis by cyclooxygenase pathway (Duarte et al., 1988). In addition, the action on the peripheral and central levels was observed, suggesting a characteristic biphasic licking response (Hunskaar and Hole, 1987). The central action was confirmed in the hot plate test (100 and $200 \mathrm{mg} / \mathrm{kg}$ ), showing maximal effect after 60 minutes of the response. These results indicated that the essential oilinduced analgesia was not dependent on the opioid system, since previous treatment with the opioid antagonist naloxone did not reverse its effect.

The results for the paw edema showed significant reduction at dose $200 \mathrm{mg} / \mathrm{kg}$. It was possible that constituents inhibited the biosynthesis of prostaglandins since studies demonstrated that the injection of carrageenan into the rat paw induced the liberation of bradykinin, which later induced the biosyntheses of prostaglandin and other autacoids, which were responsible for the formation of the inflammatory exudates (Ueno et al., 2000).

In carrageenan-induced pleurisy, the treatment with A. fastigiatum essential oil at doses 100 $\mathrm{mg} / \mathrm{kg}$ and $200 \mathrm{mg} / \mathrm{kg}$ reduced both the exudates formation and the mobilization of leukocytes. The reduction in the number of cells was more pronounced in the group of animals treated with $200 \mathrm{mg} / \mathrm{kg}$ than $100 \mathrm{mg} / \mathrm{kg}$. These observations were in agreement with results of antinociceptive activity.

These results justified the use of this plant in traditional medicine. Therefore, the essential oil from A. fastigiatum could be a potential candidate as analgesic and anti-inflammatory agent.

\section{ACKNOWLEDGEMENTS}

We thank to CNPq, CAPES for financial support and to Dr. Roberto Lourenço Esteves, from Universidade do Estado do Rio de Janeiro (Rio de Janeiro, Brazil) for plant identification.

\section{RESUMO}

A composição química e as propriedades analgésica e antiinflamatória do óleo essencial de Ageratum fastigiatum foram investigadas. Os principais constituintes do óleo essencial foram germacreno $\mathrm{D}, \alpha$-humuleno e $\beta$-cedreno. O óleo, com $\mathrm{DL}_{50}$ de $2,50 \mathrm{~g} / \mathrm{kg}$, inibiu as contorções abdominais induzidas por ácido acético na dose de $200 \mathrm{mg} / \mathrm{kg}$. No teste da formalina, o óleo inibiu a primeira fase $(200 \mathrm{mg} / \mathrm{kg})$ e a segunda fase $(100 \mathrm{e}$ $200 \mathrm{mg} / \mathrm{kg}$ ). O tempo de latência aumentou no teste da placa quente, após 30 e 60 minutos de tratamento, nas doses de 100 e $200 \mathrm{mg} / \mathrm{kg}$. O efeito antiedematogênico, assim como a redução do volume do exsudato e da migração leucocitária foram observados nas doses de 100 e $200 \mathrm{mg} / \mathrm{kg}$. Os resultados indicam que o A. fastigiatum possui propriedades analgésica e antiinflamatória, o que corrobora com o uso popular da planta. 


\section{REFERENCES}

Adams, R. P. (1995), Identification of essential oil components by Gas Chromatography/Mass Spectroscopy. Illinois, Allured Publishing Corporation.

Almeida, A. M.; Prado, P. I. and Lewinsohn, T. M. (2004), Geographical distribution of Eupatorieae (Asteraceae) in South-eastern and South Brazilian Mountain Ranges. Plant Ecol., 174, 163-181.

Atti-Santos, A. C.; Rossato, M.; Pauletti, G. F.; Rota, L. D.; Rech, J. C.; Pansera, M. R.; Agostini, F.; Serafini, L. and Moyna, P. (2005), Physico-chemical evaluation of Rosmarinus officinalis L. essential oils. Braz. Arch. Biol. Technol., 48, 1035-1039.

Bohlmann, F.; Ahmed, M.; King, R. M. and Robinson, H. (1981), Labdane and eudesmane derivatives from Ageratum fastigiatum. Phytochemistry, 20, 14341435.

Bohlmann, F.; Ludwig, G-W.; Jakupovic, J.; King, R.M. and Robinson, H. A. (1983), Daucanolide further farnesene derivatives from Ageratum fastigiatum. Phytochemistry, 22, 983-986.

Bouda, H.; Tapondjou, L. A.; Fontem, D. A.; and Gumedzoe, M. Y. D. (2001), Effect of essential oils from leaves of Ageratum conyzoides, Lantana camara and Chromolaena odorata on the mortality of Sitophilus zeamais (Coleoptera, Curculionidae). J. Stored Prod. Res., 37, 103-109.

Carvalho, J. C. T. (2004), Fitoterápicos antiinflamatórios: aspectos químicos, farmacológicos $e$ aplicações terapêuticas. Tecmedd Editora, São Paulo.

Dietrich, L. (1983), A new approach to practical acute toxicity testing. Arch. Toxicol., 54, 275-287.

Duarte, I. D. G.; Nakamura, M. and Ferreira, S.H. (1988), Participation of the sympathetic system in acetic acid-induced writhing in mice. Braz. J. Med. Biol. Res., 21, 341-343.

Franzotti, E. M.; Santos C. V. F.; Rodrigues, H. M. S. L.; Mourão, R. H. V.; Andrade M. R. and Antoniolle A. R. (2000), Anti-inflammatory, analgesic activity and acute toxicity of Sida cordifolia L. (Malvabranca). J. Ethnopharmacol., 72, 273-278.

Guimarães, A. J. M.; Araújo, G. M. and Corrêa, G. F. (2002), Estrutura fitossociológica em área natural e antropizada de uma vereda em Uberlândia, MG. Acta Bot. Bras., 16, 317-329.

Hunskaar, S. and Hole, K., (1987), The formalin test in mice: dissociation between inflammatory and noninflammatory pain. Pain, 30, 103-104.

Koster, R.; Anderson, M. and De Beer, E. J., (1959), Acetic acid for analgesic screening. Fed. Proc., 18, 412-416.

Lorenzi, H. and Matos, F. J. A. (2002), Plantas medicinais no Brasil. Instituto Plantarum, Nova Odessa.
Litchfield, J. T. and Wilcoxon, F. A. (1949), A simplified method of evaluating dose-effect experiments. J. Pharmacol. Exp. Ther., 96, 99-113.

Moody, J. O.; Adebiyi, O. A. and Adeniyi, B. A. (2004), Do Aloe vera and Ageratum conyzoides enhance the anti-microbial activity of traditional medicinal soft soaps (Osedudu)?. $J$. Ethnopharmacol., 92, 57-60.

Moura, A. C. A.; Silva, E. L. F.; Fraga, M. C. A.; Wanderley, A. G., Afiatpour, P. and Maia M. B. S. (2005), Antiinflammatory and chronic toxicity study of the leaves of Ageratum conyzoides L. in rats. Phytomedicine, 12, 138-142.

Nébié, R. H. C.; Yaméogo, R. T.; Bélager, A. and Sib, F. S. (2004), Composition chimique des huiles essentielles d'Ageratum conyzoïdes du Burkina Faso. C. R. Chim., 7, 1019-1022 (2004).

Okunade, A. L., 2002. Ageratum conyzoides L. (Asteraceae). Fiterapia, 73, 1-16.

Presibella, M. M.; Villas-Bôas, L. B.; Belletti, K. M. S.; Santos, C. A. M. and Weffort-Santos, A. M. (2006), Comparison of chemical constituents of Chamomilla recutita (L.) Rauschert essential oil and its antichemotactic activity. Braz. Arch. Biol. Technol., 49, 717-724.

Souza V. C. and Lorenzi H. (2005), Botânica sistemática: guia ilustrado para identificação das famílias de Angiospermas da flora brasileira, baseado em APG II. Instituto Plantarum, Nova Odessa.

Shirwaikar, A.; Bhilegaonkar, P. M.; Malini S. and Kumar, J. S. (2003), The gastroprotective activity of the ethanol extract of Ageratum conyzoides. J. Ethnopharmacol., 86, 117-121.

Singh H. P.; Batish D. R. and Hohli R. K. (2002), Allelopathic effect of two volatile monoterpenes against bill goat weed (Ageratum conyzoides L.). Crop Prot., 21, 347-350.

Ueno, A.; Naraba, H.; Ikeda, Y.; Ushikubi, F.; Murata, T.; Naramiya, S. and Ohishi, S. (2000), Intrinsic prostacyclin contributes to exudation induced by bradikinin or carrageenan: a study on the paw edemainduced in ip-receptor-deficient mice. Life Sci., 66, PL155-PL160.

Vinegar, R.;Traux, J. F. and Selph J. L. (1973), Some quantitative temporal characteristic of carrageenininduced pleurisy in the rat. Proc. Soc. Exp. Biol. Med., 143, 711-714.

Winter, C. A.; Risley, E. A. and Nuss G. W. (1962), Carrageenin-induced edema in hind paw of the rat as an assay for antiinflammatory drugs. Proc. Soc. Exp. Biol. Med., 111, 544-547.
Received: April 12, 2007; Revised: October 26, 2007; Accepted: August 06, 2008. 